Plant Production Science

http:/www.journals.zu.edu.eg/journalDisplay.aspx?Journalld=1\&queryType=Master

\title{
EFFECT OF PLANT SPACING AND APICAL SHOOT PINCHING ON GROWTH AND PRODUCTIVITY OF WATERMELON PLANTS UNDER SANDY SOIL CONDITIONS
}

\author{
Naglaa A.M. Anwar ${ }^{*}$, A.A. Gad, A. Bardisi and H.G. Zyada \\ Hort. Dept., Fac. Agric., Zagaizg Univ., Egypt
}

Received: 13/03/2019 ; Accepted: 02/04/2019

\begin{abstract}
The present work was carried out in Private Vegetable Farm at El- Heez, Al-Wahaat Al-Baharyia District, Giza Governorate, Egypt, during two successive summer seasons of 2016 and 2017, to study the effect of plant spacing and apical shoot pinching (ASP) stage on growth and productivity of watermelon plants under sandy soil conditions using drip irrigation system. Results showed that, the interaction between plant spacing at $30 \mathrm{~cm}$ and ASP at the $6^{\text {th }}$ node gave the tallest plants, whereas the interaction between plant spacing at $60 \mathrm{~cm}$ and ASP at the $6^{\text {th }}$ node gave the highest values for each of number of leaves and branches/plant at 45 days after planting. On the other side, planting watermelon at $45 \mathrm{~cm}$ and ASP at the $6^{\text {th }}$ node increased average number of fruits/ plant, average fruit weight, yield/plant and total yield/faddan.
\end{abstract}

Key words: Watermelon, Citrullus lanatus, plant spacing, apical shoot pinching, growth and yield.

\section{INTRODUCTION}

Watermelon (Citrullus lanatus, Thumb.) is one of the important vegetables crops in Egypt. The major nutritional components of the fruit are carbohydrates, vitamin A and lycopene, and anti-carcinogenic compound found in red flesh watermelon. Lycopene may help reduce the risk of certain cancer of prostrate gland, pancreas and stomach.

The total watermelon cultivated area in 2017 in Egypt, was 131, 215 fad., which produced 1, 709,964 tons with average 13.03 ton/fad., (FAO, 2017). About $50-53 \%$ of watermelon cultivation area during that period was cultivated in new reclaimed land using drip irrigation system. Watermelon production in Egypt is meanly conducted during the summer season in open fields, but about 10 percent of its cultivation area is grown under plastic low tunnel conditions during winter season.

Culture practices such as irrigation, cultivation, planting spacing, chose of cultivar, control of

\footnotetext{
* Corresponding author: Tel. : +201004655525

E-mail address: ne.anwar@zu.edu.eg
}

weeds, insect pests and diseases play important roles in determining yields of watermelon (Taylor et al., 2003).

Adequate plant spacing strategies and nutrient management has been reported to have a positive impact on watermelon yield (Goreta et al., 2005).

Inappropriate plant density has accounted for poor yields of this crop among most small scale watermelon farmers. If plants are widely spaced, not all land area is covered by leaves and much of light available for photosynthesis is wasted, so also water and mineral resources in the soil. But if plants are closely spaced, competition for water and minerals in the soil, as well as light will occur among plants because their leaves will begin to shade one another (Forbes and Watson, 1992). High plant density is recommended for watermelon seed production because more fruits per area is achieved at a denser spacing (Edelstein and Nerson, 2002).

In the production of watermelon, plant spacing is a major problem faced by farmers in 
their production. The use of spacing in crop production is very important and good because it reduces competition between plants and weeds. When adequate spacing is done in plant production, it increases crop growth and yield. Generally, in Watermelon, the yield and number of fruits per unit area increased with increased crop density, whereas the yield and number of fruits per plant decreased. High planting density increased the number of fruits per area (NeSmith, 1993). However, some studies showed that average weight of fruits decreases with increase in plant density (Motsenbocker and Arancibia, 2002). Competition for water and nutrients in dense plant stands might be responsible for the decrease in plant growth and yield (Knavel, 1988).

Dantata (2014) found that planting watermelon at $100 \mathrm{~cm}$ increased vine length, number of leaves, number of fruits/plant and fruit yield/ha., followed by planting at $75 \mathrm{~cm}$. Aldan and Abu Sarra (2018) indicated that $70 \mathrm{~cm}$ intra-row spacing with one plant/hill gave the optimum plant density for watermelon, since it resulted in optimum growth and the highest marketable yield and best quality

In watermelon, apical shoots are pinched when the vines are $1 \mathrm{~m}$ while allowing the side shoots to grow. This practice gives significantly higher fruit yield. At the initial stages of fruit setting, malformed, diseased and damaged fruits are removed and only 2-3 fruits per vine are retained. This results in increased fruit size and yield.

Pruning is an act of cutting off plant branches so as to encourage flowering or fruiting. Shoots, flowers and fruits are pruned to maintain a proper balance between the vegetative growth and fruit load. This will maximize production (Wayne, 1990). Watermelon vine pruning treatments can serve these purposes: to enhance mechanical harvesting, production of hybrid seed, ease of control of pests and diseases, use of higher plant population without significant yield reduction and the production of uniform fruits (Jarrick, 1986).

Oga and Umekwe (2016) indicated that the pruned watermelon plants produced the longest vine, number of leaves, number of flowers and number of fruits.
Pinching at the $6^{\text {th }}$ node increased number of branches/plant of cucurbita moschata (Eve et al. 2016) and number of fruits, yield per vine and yield per hectare of cucumber (Nayak et al. 2018).

Therefore, the aim of this study was to determine the suitable plant spacing and apical shoot pinching stages to obtain maximum yield with good quality of watermelon grown under sandy soil conditions using drip irrigation system.

\section{MATERIALS AND METHODS}

The present study was carried out in Private Vegetable Farm at El-Heez, Al-Wahaat Al-Baharyia District, Giza Governorate, Egypt, during two successive summer seasons of 2016 and 2017, to study the effect of plant spacing and apical shoot pinching (ASP) stage on growth and productivity of watermelon plants under sandy soil conditions using drip irrigation system.

This experiment included 18 treatments which were the combinations between 3 plant spacings and 6 apical shoot pinching (ASP) stages as follows:

\section{A. Plant spacing: 30,45 and $60 \mathrm{~cm}$.}

B. Apical shoot pinching (ASP) stages: Without ASP (control), ASP at the $4^{\text {th }}$, the $6^{\text {th }}$, the $8^{\text {th }}$, the $10^{\text {th }}$ and the $12^{\text {th }}$ node.

These treatments were arranged in a split plot in a complete randomized block design with three replicates. Plant spacings were randomly arranged in the main plots and ASP stages were randomly distributed in the sub plots. The watermelon plants were pinched manually by removing the apical shoots for leaving $4,6,8$, 10 and 12 nodes, respectively.

Plant spacings, plant densities and plant populations of watermelon plants are presented in Schedule 1.

The experimental unit area was $18 \mathrm{~m}^{2}$. It contains two ridges with $6 \mathrm{~m}$ length and $1.5 \mathrm{~m}$ distance between each two ridges. One ridge was used to measure the morphological traits and the other was used for yield determination. 
Zagazig J. Agric. Res., Vol. 46 No. (2) 2019

Schedule 1. Plant spacing, plant densities and plant populations of watermelon plants

\begin{tabular}{lcc}
\hline Plant spacings & Plant densities $\left(\right.$ plant $\left./ \mathbf{m}^{2}\right)$ & Plant populations (plant/fad.) \\
\hline $\mathbf{3 0} \mathbf{~ c m}$ & 2.22 & 9324 \\
$\mathbf{4 5} \mathbf{~ c m}$ & 1.48 & 6216 \\
$\mathbf{6 0} \mathbf{~ c m}$ & 1.11 & 4662 \\
\hline
\end{tabular}

The distance between each two ridges $=1.5 \mathrm{~m}$.

The seeds of watermelon Giza 1 cultivar were sown on $10^{\text {th }}$ and $18^{\text {th }} \mathrm{Feb}$. in seedling trays in the $1^{\text {st }}$ and $2^{\text {nd }}$ seasons, respectively. Transplants were transplanted on $7^{\text {th }}$ and $15^{\text {th }}$ March on one side of the ridge $(1.5 \mathrm{~m})$ in the $1^{\text {st }}$ and $2^{\text {nd }}$ seasons, respectively.

The sources of nitrogen, potassium and phosphorus fertilizers were ammonium sulphate $(20.5 \% \mathrm{~N})$ and ammonium nitrate $(33.5 \% \mathrm{~N})$ at 100 and $150 \mathrm{~kg} / \mathrm{fad}$., respectively, potassium sulphate $\left(48 \% \mathrm{~K}_{2} \mathrm{O}\right)$ at $200 \mathrm{~kg} /$ fad., and calcium superphosphate $\left(15.5 \% \mathrm{P}_{2} \mathrm{O}_{5}\right)$ and phosphoric acid at $150 \mathrm{~kg}$ and $20 \mathrm{l}$./fad., respectively. All experimental units received equal amounts of FYM at $20 \mathrm{~m}^{3} /$ fad., ammonium sulphate and calcium superphosphate during soil preparation. All plants were fertilized with ammonium nitrate, phosphoric acid and potassium sulphate as fertigation at equal doses two times weekly from 10 and 60 days after transplanting, the other cultivated practices for watermelon production were used according to the instruction laid down by the Ministry of Agriculture, Egypt.

\section{Data Recorded}

\section{Vegetative growth}

At flowering stage (45 days after transplanting), main vine length, number of leaves/plant, and number of lateral branches were measured.

\section{Yield and its components}

Watermelons were harvested by hand when the fruit matured (75-80 days after transplanting), in general, fruit were considered mature when the tendril nearest to fruit start to dry, and color of fruit on the bottom side changed from creamy white to yellowish. Fruits were weighed, then average fruit weight $(\mathrm{kg})$ and total yield (ton/ fad.) were calculated.

\section{Statistical Analysis}

Statistical analysis was conducted for all collected data. The analysis of variance was calculated according to Snedecor and Cochran (1980), means separation was done according to LSD at 0.05 level.

\section{RESULTS AND DISCUSSION}

\section{Plant Growth}

\section{Effect of plant spacing}

Results in Table 1 show that planting watermelon plants grown in sandy soil at $30 \mathrm{~cm}$ recorded the tallest plants, whereas planting at $60 \mathrm{~cm}$ recorded the shortest plants. Planting at $60 \mathrm{~cm}$ gave the highest value for each of number of leaves/plant and number of branches/plant, whereas planting at $45 \mathrm{~cm}$ gave the lowest values at flowering stage (45 days after transplanting in both seasons.

From the foregoing results, it could be concluded that, narrow spacing gave the tallest plant, whereas wider spacing gave the highest value for each of number of leaves and branches/plant. Competition for water and nutrients in dense plant stands might be responsible for the decrease in plant growth and yield (Knavel, 1988).

\section{Effect of apical shoot pinching}

The obtained results in Table 2 indicate that apical shoot pinching (ASP) at the $6^{\text {th }}$ node recorded the tallest plants and gave the highest value for each of number of leaves and number of branches/plant, whereas Asp at $12^{\text {th }}$ node recorded the shortest plants at 45 days after planting in both seasons. These results agree with those reported by Eve et al. (2016) and Oga and Umekwe (2016). 
Table 1. Effect of plant spacing on vegetative growth of watermelon plants at 45 days after planting during 2016 and 2017 seasons

\begin{tabular}{lccc}
\hline Plant spacing & Plant length (cm) & Number of leaves/plant & Number of branches/plant \\
\hline & & $\mathbf{2 0 1 6}$ season & \\
$\mathbf{3 0} \mathbf{~ c m}$ & 201.35 & 201.44 & 7.55 \\
$\mathbf{4 5} \mathbf{~ c m}$ & 181.73 & 171.83 & 6.21 \\
$\mathbf{6 0} \mathbf{~ c m}$ & 163.90 & 229.34 & 8.16 \\
$\mathbf{L S D}$ at $\mathbf{0 . 0 5}$ level & $\mathbf{1 1 . 9 9}$ & $\mathbf{8 . 1 6}$ & $\mathbf{0 . 4 3}$ \\
& & $\mathbf{2 0 1 7}$ season & \\
$\mathbf{3 0} \mathbf{~ c m}$ & 194.35 & 226.05 & 8.33 \\
$\mathbf{4 5} \mathbf{~ c m}$ & 180.93 & 173.45 & 6.11 \\
$\mathbf{6 0} \mathbf{~ c m}$ & 168.40 & 246.13 & 8.00 \\
$\mathbf{L S D}$ at $\mathbf{0 . 0 5}$ level & $\mathbf{5 . 7 7}$ & $\mathbf{6 . 5 2}$ & $\mathbf{0 . 2 9}$ \\
\hline
\end{tabular}

Table 2. Effect of apical shoot pinching on vegetative growth of watermelon plants at 45 days after planting during 2016 and 2017 seasons

\begin{tabular}{|c|c|c|c|}
\hline$\overline{\mathbf{A S P}}$ & Plant length (cm) & Number of leaves/plant & Number of branches/plant \\
\hline & \multicolumn{3}{|c|}{2016 season } \\
\hline Without ASP & 201.10 & 185.21 & 6.55 \\
\hline ASP at the $4^{\text {th }}$ node & 182.47 & 204.67 & 7.66 \\
\hline ASP at the $6^{\text {th }}$ node & 228.57 & 261.43 & 8.88 \\
\hline ASP at the $8^{\text {th }}$ node & 156.23 & 191.13 & 7.55 \\
\hline ASP at the $10^{\text {th }}$ node & 176.47 & 213.43 & 7.66 \\
\hline ASP at the $12^{\text {th }}$ node & 149.13 & 149.36 & 5.55 \\
\hline \multirow[t]{2}{*}{ LSD at 0.05 level } & 8.32 & 7.41 & 0.45 \\
\hline & \multicolumn{3}{|c|}{2017 season } \\
\hline Without ASP & 201.00 & 214.70 & 7.22 \\
\hline ASP at the $4^{\text {th }}$ node & 178.00 & 188.10 & 8.00 \\
\hline ASP at the $6^{\text {th }}$ node & 231.43 & 333.13 & 9.88 \\
\hline ASP at the $8^{\text {th }}$ node & 156.00 & 187.80 & 6.22 \\
\hline ASP at the $10^{\text {th }}$ node & 171.37 & 202.77 & 7.66 \\
\hline ASP at the $12^{\text {th }}$ node & 149.57 & 164.77 & 5.88 \\
\hline LSD at 0.05 level & 8.18 & 6.51 & 0.30 \\
\hline
\end{tabular}


Effect of the interaction between plant spacing and ASP

Results in Table 3 illustrate that the interaction between plant spacing at $30 \mathrm{~cm}$ and ASP at the $6^{\text {th }}$ node recorded the tallest plants with no significant differences with the interaction between plant spacing at $45 \mathrm{~cm}$ and ASP at $6^{\text {th }}$ node, whereas the interaction between plant spacing at $60 \mathrm{~cm}$ and ASP at the $12^{\text {th }}$ node recorded the shortest plants. The interaction between plant spacing at $60 \mathrm{~cm}$ and ASP at the $6^{\text {th }}$ node recorded the highest value of number of leaves/plant with no significant differences with the interaction between plant spacing at $30 \mathrm{~cm}$ and ASP at $6^{\text {th }}$ node as for number of branches/plant. The interaction between plant spacing at $60 \mathrm{~cm}$ and ASP at $6^{\text {th }}$ node and the interaction between plant spacing at $30 \mathrm{~cm}$ and ASP at $6^{\text {th }}$ node gave the highest number of branches/plant in the $1^{\text {st }}$ and $2^{\text {nd }}$ seasons, respectively.

From the foregoing results, it could be concluded that, the interaction between plant spacing at $30 \mathrm{~cm}$ and ASP at the $6^{\text {th }}$ node gave the tallest plants, whereas the interaction between plant spacing at $60 \mathrm{~cm}$ and ASP at the $6^{\text {th }}$ node gave the highest value for each of number of leaves and branches/plant at 45 days after planting.

\section{Yield and its Components}

\section{Effect of plant spacing}

Results in Table 4 show that planting watermelon plants grown in sandy soil at 45 or $60 \mathrm{~cm}$ increased average number of fruits/plant compared to planting at $30 \mathrm{~cm}$. Planting at 45 $\mathrm{cm}$ gave the highest value for each of average fruit weight and yield/plant, followed by planting at $60 \mathrm{~cm}$ in both seasons. As for total yield/fad., planting at $45 \mathrm{~cm}$ increased total yield, followed by planting at $30 \mathrm{~cm}$ compared to planting at $60 \mathrm{~cm}$.

Generally, in watermelon, the yield and number of fruits per unit are increased with increased crop density, whereas the yield and number of fruits/plant decreased. High planting density increased the number of fruits per area (NeSmith, 1993). However, some studies showed that average weight of fruits decreases with increase in plant density (Motsenbocker and Arancibia, 2002). Competition for water and nutrients in dense plant stands might be responsible for the decrease in plant growth and yield (Knavel, 1988).

From the foregoing results, it could be concluded that, plant spacing at $45 \mathrm{~cm}$ increased average fruit weight and yield/plant followed by plant spacing at $60 \mathrm{~cm}$, whereas plant spacing at $45 \mathrm{~cm}$ increased total yield/fad., followed by plant spacing at $30 \mathrm{~cm}$.

\section{Effect of apical shoot pinching}

Results in Table 5 show that ASP at the 4 and the $6^{\text {th }}$ node gave the highest value for each of average number of fruits/plant, average fruit weight, yield/plant and total yield /fad, followed by without ASP, whereas ASP at the 8,10 and $12^{\text {th }}$ node gave the lowest values.

From the foregoing results, it could be concluded that, ASP at the 4 or the $6^{\text {th }}$ node increased average number of fruits/plant, average fruit weight, yield/plant and total yield/ fad., compared without ASP and ASP at the 8,10 and $12^{\text {th }}$ node. These results agree with those reported by Nayak et al. (2018).

The simulative effect of ASP at the $6^{\text {th }}$ node on yield of watermelon may be due to that ASP node increased vine length, number of leaves and number of branches/plant (Table 2), therefore there was positive correlation between number of fruits and both vine length and number of branches/ plant of watermelon. In this respect, Warren et al. (1998) indicated that watermelon plants with many branches produce higher yields than those with few branches or those whose branches have been pruned. This was confirmed by a strong and highly significant correlation that was observed between branch number and fruit number. Also, they found that watermelon plants with longer vines produce higher yields than those with shorter vines. This was confirmed by a strong and highly significant position correlation that was observed between main vine length and fruit number

Also, Warren et al. (1998) indicated that more watermelon foliage translates into high photosynthetic and assimilation rates and ultimately more fruits, and any reduction in foliage reduces fruit yields. They added that watermelon plants with longer vines also produce 
Table 3.Effect of the interaction between plant spacing and apical shoot pinching on growth of watermelon plants at 45 days after planting during 2016 and 2017 seasons

\begin{tabular}{|c|c|c|c|c|c|c|c|}
\hline \multirow[b]{2}{*}{ Plant spacing } & \multirow[b]{2}{*}{ ASP } & \multicolumn{2}{|c|}{$\begin{array}{l}\text { Plant length } \\
\text { (cm) }\end{array}$} & \multicolumn{2}{|c|}{$\begin{array}{l}\text { Number of } \\
\text { leaves/plant }\end{array}$} & \multicolumn{2}{|c|}{$\begin{array}{c}\text { Number of } \\
\text { branches/plant }\end{array}$} \\
\hline & & $\begin{array}{c}2016 \\
\text { season }\end{array}$ & $\begin{array}{c}2017 \\
\text { season }\end{array}$ & $\begin{array}{c}2016 \\
\text { season }\end{array}$ & $\begin{array}{c}2017 \\
\text { season }\end{array}$ & $\begin{array}{c}2016 \\
\text { season }\end{array}$ & $\begin{array}{c}2017 \\
\text { season }\end{array}$ \\
\hline \multirow[t]{6}{*}{$30 \mathrm{~cm}$} & Without ASP & 235.70 & 241.00 & 176.33 & 188.70 & 5.33 & 7.33 \\
\hline & ASP at the $4^{\text {th }}$ node & 214.70 & 220.70 & 193.30 & 217.30 & 9.33 & 10.00 \\
\hline & ASP at the $6^{\text {th }}$ node & 248.00 & 250.30 & 286.00 & 387.00 & 8.66 & 12.00 \\
\hline & ASP at the $8^{\text {th }}$ node & 167.70 & 153.70 & 205.70 & 184.00 & 7.66 & 6.33 \\
\hline & ASP at the $10^{\text {th }}$ node & 220.00 & 177.70 & 207.30 & 213.30 & 8.33 & 8.33 \\
\hline & ASP at the $12^{\text {th }}$ node & 122.00 & 122.70 & 140.00 & 166.00 & 6.00 & 6.00 \\
\hline \multirow[t]{6}{*}{$45 \mathrm{~cm}$} & Without ASP & 183.30 & 187.70 & 183.30 & 187.70 & 5.66 & 6.00 \\
\hline & ASP at the $4^{\text {th }}$ node & 141.70 & 145.30 & 159.70 & 145.30 & 6.00 & 7.00 \\
\hline & ASP at the $6^{\text {th }}$ node & 264.00 & 252.30 & 209.30 & 238.70 & 7.66 & 8.00 \\
\hline & ASP at the $8^{\text {th }}$ node & 161.00 & 179.30 & 157.00 & 154.70 & 5.33 & 5.66 \\
\hline & ASP at the $10^{\text {th }}$ node & 140.70 & 130.70 & 184.00 & 161.30 & 6.66 & 5.00 \\
\hline & ASP at the $12^{\text {th }}$ node & 199.70 & 190.30 & 137.70 & 153.00 & 6.00 & 5.00 \\
\hline \multirow[t]{6}{*}{$60 \mathrm{~cm}$} & Without ASP & 184.30 & 174.30 & 196.00 & 267.70 & 8.66 & 8.33 \\
\hline & ASP at the $4^{\text {th }}$ node & 191.00 & 168.00 & 261.00 & 201.70 & 7.66 & 7.00 \\
\hline & ASP at the $6^{\text {th }}$ node & 173.70 & 191.70 & 289.00 & 373.70 & 10.33 & 9.66 \\
\hline & ASP at the $8^{\text {th }}$ node & 140.00 & 135.00 & 210.70 & 224.70 & 9.66 & 6.66 \\
\hline & ASP at the $10^{\text {th }}$ node & 168.70 & 205.70 & 249.00 & 233.70 & 8.00 & 9.66 \\
\hline & ASP at the $12^{\text {th }}$ node & 125.70 & 135.70 & 170.37 & 175.30 & 4.66 & 6.66 \\
\hline \multicolumn{2}{|c|}{ LSD at 0.05 level } & 14.41 & 14.17 & 12.83 & 11.28 & 0.78 & 0.52 \\
\hline
\end{tabular}

ASP: apical shoot pinching

Table 4. Effect of plant spacing on yield and its components of watermelon plants during 2016 and 2017 seasons

\begin{tabular}{lcccc}
\hline Plant spacing & $\begin{array}{c}\text { Average number } \\
\text { of fruits/plant }\end{array}$ & $\begin{array}{c}\text { Average fruit } \\
\text { weight (kg) }\end{array}$ & $\begin{array}{c}\text { Yield/plant } \\
\text { (kg) }\end{array}$ & $\begin{array}{c}\text { Yield/fad. } \\
\text { (ton) }\end{array}$ \\
\hline & \multicolumn{4}{c}{$\mathbf{2 0 1 6}$ season } \\
$\mathbf{3 0 ~ c m}$ & 1.457 & 3.946 & 5.879 & 39.193 \\
$\mathbf{4 5} \mathbf{~ c m}$ & 1.972 & 4.675 & 9.504 & 42.237 \\
$\mathbf{6 0} \mathbf{~ c m}$ & 2.034 & 4.143 & 8.680 & 30.478 \\
$\mathbf{L S D}$ at $\mathbf{0 . 0 5}$ level & $\mathbf{0 . 1 3}$ & $\mathbf{0 . 1 3 6}$ & $\mathbf{0 . 8 0 5}$ & $\mathbf{4 . 3 1 7}$ \\
& \multicolumn{4}{c}{$\mathbf{2 0 1 7}$ season } \\
$\mathbf{3 0} \mathbf{~ c m}$ & 1.567 & 3.953 & 6.259 & 41.725 \\
$\mathbf{4 5} \mathbf{~ c m}$ & 2.069 & 5.062 & 10.825 & 48.105 \\
$\mathbf{6 0} \mathbf{~ c m}$ & 2.006 & 4.451 & 9.192 & 32.312 \\
$\mathbf{L S D}$ at $\mathbf{0 . 0 5}$ level & $\mathbf{0 . 2 4}$ & $\mathbf{0 . 1 8 0}$ & $\mathbf{1 . 2 3 5}$ & $\mathbf{6 . 7 9 4}$ \\
\hline
\end{tabular}


Table 5. Effect of apical shoot pinching on yield and its components of watermelon plants during 2016 and 2017 seasons

\begin{tabular}{|c|c|c|c|c|}
\hline ASP & $\begin{array}{l}\text { Average number } \\
\text { of fruits/plant }\end{array}$ & $\begin{array}{l}\text { Average fruit } \\
\text { weight (kg) }\end{array}$ & $\begin{array}{c}\text { Yield/plant } \\
\text { (kg) }\end{array}$ & $\begin{array}{l}\text { Yield/fad. } \\
\text { (ton) }\end{array}$ \\
\hline & \multicolumn{4}{|c|}{2016 season } \\
\hline Without ASP & 1.666 & 4.336 & 7.219 & 36.048 \\
\hline ASP at the $4^{\text {th }}$ node & 2.152 & 5.406 & 11.693 & 53.453 \\
\hline ASP at the $6^{\text {th }}$ node & 2.235 & 5.264 & 11.990 & 54.574 \\
\hline ASP at the $8^{\text {th }}$ node & 1.610 & 3.533 & 5.698 & 26.865 \\
\hline ASP at the $10^{\text {th }}$ node & 1.790 & 3.620 & 6.517 & 30.494 \\
\hline ASP at the $12^{\text {th }}$ node & 1.473 & 3.368 & 5.013 & 22.383 \\
\hline \multirow[t]{2}{*}{ LSD at 0.05 level } & 0.19 & 0.298 & 1.147 & 5.188 \\
\hline & \multicolumn{4}{|c|}{2017 season } \\
\hline Without ASP & 1.805 & 4.616 & 8.342 & 42.535 \\
\hline ASP at the $4^{\text {th }}$ node & 2.165 & 5.616 & 12.416 & 55.991 \\
\hline ASP at the $6^{\text {th }}$ node & 2.207 & 5.450 & 12.463 & 55.165 \\
\hline ASP at the $8^{\text {th }}$ node & 1.748 & 3.883 & 6.823 & 32.400 \\
\hline ASP at the $10^{\text {th }}$ node & 1.750 & 3.878 & 6.841 & 32.166 \\
\hline ASP at the $12^{\text {th }}$ node & 1.610 & 3.488 & 5.667 & 26.026 \\
\hline LSD at 0.05 level & 0.20 & 0.249 & 1.216 & 5.386 \\
\hline
\end{tabular}

ASP: apical shoot pinching

higher yields than those with shorter vines. Since watermelon flowers develop in the nodes of the plants, additional branching on some watermelon accessions creates more locations for the flowers to develop (Dittmar et al., 2006).

There was a strong and highly significant positive correlation between the number of branches on the main vine and fruit number of watermelon. There was a strong and highly significant positive correlation between fruit number and branch number. There was a strong and highly significant positive correlation between the number of female flowers and fruit number (Gichimu et al., 2009).

Effect of the interaction between plant spacing and ASP

The obtained results in Table 6 indicate that the interaction between plant spacing at 45 or at $60 \mathrm{~cm}$ and ASP at the $4^{\text {th }}$ or at the $6^{\text {th }}$ node in the $1^{\text {st }}$ season and the interaction between plant spacing at 45 or at $60 \mathrm{~cm}$ and ASP at $4^{\text {th }}$ node or without ASP in the $2^{\text {nd }}$ season increased average number of fruits/ plant. The interaction between plant spacing at $45 \mathrm{~cm}$ and ASP at the $6^{\text {th }}$ node increased average fruit weight, yield/plant and total yield/fad., with no significant differences with the interaction between plant spacing at 45 $\mathrm{cm}$ and ASP at the $4^{\text {th }}$ node with respect to yield/plant and total yield/fad., in the $2^{\text {nd }}$ season.

From the foregoing results, it could be concluded that, planting watermelon plants in sandy soil at $45 \mathrm{~cm}$ and ASP at the $6^{\text {th }}$ node increased average number of fruits/plant, average fruit weight, yield/plant and total yield/ faddan.

Pruning is an act of cutting off plant branches so as to encourage flowering or fruiting. Shoots, flowers and fruits are pruned to maintain a proper balance between the vegetative growth and fruit load. This will maximize production (Wayne, 1990). Watermelon vine pruning treatments can serve these purposes: to enhance mechanical harvesting, production of hybrid seed, ease of control of pests and diseases, use of higher plant population without significant yield reduction and the production of uniform fruits (Jarrick, 1986). 
Table 6. Effect of the interaction between plant spacing and apical shoot pinching on yield and its components of watermelon during 2016 and 2017 seasons

\begin{tabular}{|c|c|c|c|c|c|c|c|c|c|}
\hline \multirow{2}{*}{$\begin{array}{l}\text { Treatment } \\
\text { Spacing }\end{array}$} & \multirow[b]{2}{*}{ ASP } & \multicolumn{2}{|c|}{$\begin{array}{c}\text { Average number } \\
\text { of fruits/plant }\end{array}$} & \multicolumn{2}{|c|}{$\begin{array}{l}\text { Average fruit } \\
\text { weight (kg) }\end{array}$} & \multicolumn{2}{|c|}{$\begin{array}{l}\text { Yield/plant } \\
\text { (kg) }\end{array}$} & \multicolumn{2}{|c|}{$\begin{array}{l}\text { Yield/fad. } \\
\text { (ton) }\end{array}$} \\
\hline & & $\begin{array}{c}2016 \\
\text { season }\end{array}$ & $\begin{array}{c}2017 \\
\text { season }\end{array}$ & $\begin{array}{c}2016 \\
\text { season }\end{array}$ & $\begin{array}{c}2017 \\
\text { season }\end{array}$ & $\begin{array}{c}2016 \\
\text { season }\end{array}$ & $\begin{array}{c}2017 \\
\text { season }\end{array}$ & $\begin{array}{c}2016 \\
\text { season }\end{array}$ & $\begin{array}{c}2017 \\
\text { season }\end{array}$ \\
\hline \multirow[t]{6}{*}{$30 \mathrm{~cm}$} & Without ASP & 1.333 & 1.746 & 4.038 & 4.415 & 5.354 & 7.374 & 35.691 & 49.156 \\
\hline & ASP at the $4^{\text {th }}$ node & 1.706 & 1.540 & 5.188 & 4.475 & 8.875 & 7.806 & 59.161 & 52.032 \\
\hline & ASP at the $6^{\text {th }}$ node & 1.706 & 1.580 & 4.540 & 4.191 & 7.746 & 6.471 & 51.637 & 43.132 \\
\hline & ASP at the $8^{\text {th }}$ nods & 1.373 & 1.500 & 3.471 & 3.741 & 4.782 & 5.903 & 31.877 & 39.346 \\
\hline & ASP at the $10^{\text {th }}$ node & 1.496 & 1.373 & 3.491 & 3.695 & 5.208 & 5.601 & 34.714 & 37.335 \\
\hline & ASP at the $12^{\text {th }}$ node & 1.126 & 1.750 & 2.951 & 3.200 & 3.312 & 4.403 & 22.078 & 29.347 \\
\hline \multirow[t]{6}{*}{$45 \mathrm{~cm}$} & Without ASP & 1.666 & 2.500 & 4.773 & 4.926 & 7.955 & 8.607 & 35.350 & 38.248 \\
\hline & ASP at the $4^{\text {th }}$ node & 2.250 & 2.500 & 5.548 & 6.408 & 12.479 & 16.031 & 55.457 & 71.243 \\
\hline & ASP at the $6^{\text {th }}$ node & 2.500 & 1.916 & 6.468 & 6.941 & 16.214 & 17.381 & 72.056 & 77.242 \\
\hline & ASP at the $8^{\text {th }}$ node & 1.750 & 2.000 & 3.976 & 4.383 & 6.921 & 8.375 & 30.756 & 37.218 \\
\hline & ASP at the $10^{\text {th }}$ node & 2.000 & 1.750 & 4.030 & 4.250 & 8.066 & 8.483 & 35.846 & 37.700 \\
\hline & ASP at the $12^{\text {th }}$ node & 1.666 & 2.000 & 3.253 & 3.466 & 5.391 & 6.071 & 23.957 & 26.979 \\
\hline \multirow[t]{6}{*}{$60 \mathrm{~cm}$} & Without ASP & 2.000 & 2.250 & 4.198 & 4.508 & 8.349 & 9.046 & 37.102 & 40.200 \\
\hline & ASP at the $4^{\text {th }}$ node & 2.500 & 2.583 & 5.483 & 5.966 & 13.723 & 13.410 & 45.740 & 44.697 \\
\hline & ASP at the $6^{\text {th }}$ node & 2.500 & 1.750 & 4.785 & 5.216 & 12.010 & 13.537 & 40.031 & 45.120 \\
\hline & ASP at the $8^{\text {th }}$ node & 1.706 & 1.750 & 3.151 & 3.525 & 5.390 & 6.192 & 17.963 & 20.637 \\
\hline & ASP at the $10^{\text {th }}$ node & 1.873 & 1.706 & 3.340 & 3.691 & 6.277 & 6.440 & 20.921 & 21.463 \\
\hline & ASP at the $12^{\text {th }}$ node & 1.626 & 1.746 & 3.901 & 3.800 & 6.335 & 6.527 & 21.113 & 21.753 \\
\hline \multicolumn{2}{|c|}{ LSD at 0.05 level } & 0.33 & 0.36 & 0.516 & 0.432 & 1.988 & 2.107 & 8.986 & 9.329 \\
\hline
\end{tabular}

ASP: apical shoot pinching

\section{REFERENCES}

Adlan, M.A.A. and A.F. Abu Sarra (2018). Effects of plant density on yield and quality of watermelon (Citrullus lanatus Thunb) under Gezira conditions, Sudan. Hort. Int. J., 2 (4): $158-162$.

Dantata (2014). Assessing watermelon cultivars under different planting distances in Bauchi North, Nigeria. Asian J. Appl. Sci., 2 (3): 381-386.
Dittmar, P.J., J.R. Schultheis and D.W. Monks (2006). Characterization of diploid watermelon pollenizers and utilization for optimal triploid watermelon production and effects of Halosulfuron POST and POST-DIR on Watermelon. MSc. Thesis. North Carolina State Univ.

Edelstein, M. and H. Nerson (2002). Genotype and plant density effect on watermelon growth for seed consumption. Hort. Sci., $2725-2740$. 
Eve, B., M. Tuarira and M. Moses (2016). The influence of pinching on the growth, flowering pattern and yield of butternuts (Cucurbita moschata). Int. J. Hort. and Ornamental Plants, 2 (1): 19-25.

FAO (2017). Food and Agriculture Organization of the United Nations.

Forbes, F.C. and R.D. Watson (1992). Plant in agriculture. $1^{\text {st }}$ Ed., press syndicate of the Univ. Camb., Camb., New York, ISBN: 97805214.

Gichimu B.M., B.O. Owuor, G.N. Mwai and M.M. Dida (2009). Morphological characterization of some wild and cultivated watermelon (Citrullus sp.) accession in Kenya. ARPN J. Agric. Biol. Sci., 4: 19906145.

Goreta, S., S. Perica, G. Dumičić, L. Bućan and K. Žanić (2005). Growth and yield of watermelon on polyethylene mulch with different spacings and nitrogen rates. Hort. Sci., 40 (2): 366-369.

Jarrick, J. (1986). Training and pruning. Hort. Sci., 400.

Knavel, D.E. (1988). Growth, development, and yield potential of short-internode muskmelon. J. Amer. Soc. Hort. Sci., 113: 595-599.

Motsenbocker, C.E. and R.A. Arancibia (2002). In-row spacing influences on triploid watermelon yield and crop value. Hort. Technol., 12: 437 - 440.

Nayak, S.R., V.K. Parmar, A.N. Patel, J. Suchismita, J.B. Lathiya and Y.N. Tandel
(2018). Efficacy of pinching and plant growth regulators in enhancing yield characters of cucumber (Cucumis sativus L.) Inter. J. Chem. Studies, 6 (1): 1804-1807.

NeSmith, D.S. (1993): Plant spacing influences watermelon yield and yield components. Hort. Sci., 28: 885 - 887.

Oga, I.O. and P.N. Umekwe (2016). Effects of pruning and plant spacing on the growth and yield of watermelon (Citrullus lanatus L.) in Unwana-Afikpo. Int. J. Sci. Res., 5 (4): 110115.

Snedecor, G.W. and W.G. Cochran (1980). Statistical Methods, $7^{\text {th }}$ Ed. Iowa State Univ. Press. Ames. Iowa, USA.

Taylor, M.J., Lu. Wenhua, A. James, B. Duthie, R. Warren and V.E. Jonathan (2003). Effects of high and low management intensity on profitability for three watermelon genotypes. Paper presented at the evaluation of production alternatives 1 session of the Southern Agricultural Economics Association. Annual hetting, Mobil, Alabama, February 15, 2003.

Warren, R., J. Duthie, J. Edelson, J. Shrefler and M. Taylor (1998). Relationship between watermelon foliage and fruit. In: Proceedings of the $17^{\text {th }}$ Ann. Hort. Industries Show, 229234. January 9-10.

Wayne, V. (1990). Greenhouse cucumber production. University of Alaska Fairbanks Cooperative Extension Service. HGA-00434.

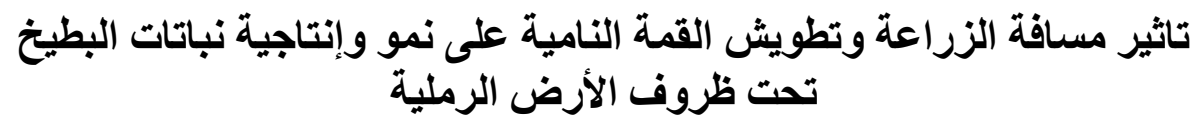

نجلاء الشحات محمد أنور- عبد المنعم عامر جادـ عبد الله برديسى ـ هانى جمال زياده

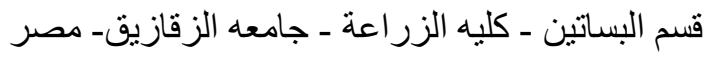

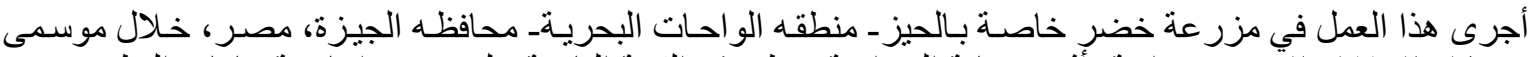

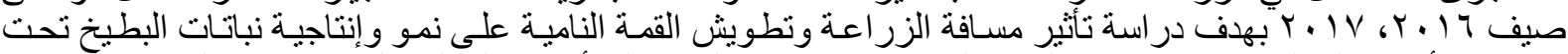

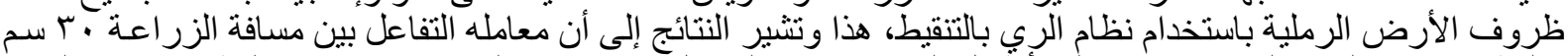

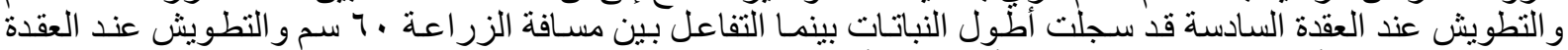

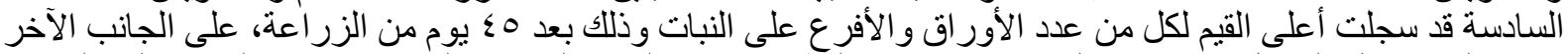

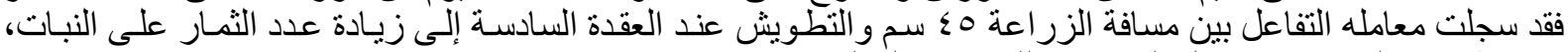
متوسط وزن الثمرة ومحصول النبات وكذلك محصول الفيل الفدان.

رئيس بحوث بمعهد بحوث البسانين- مركز البحوث الزراعية.

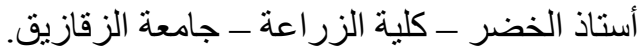

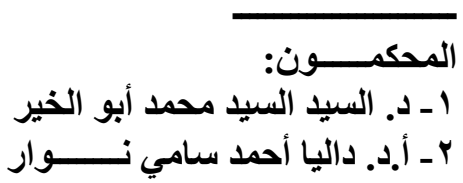

